\title{
An Incomplete Discussion on the Costs of Obesity
}

\section{Phillipe Augusto Ferreira Rodrigues', Murilo Mariano Vilaça², Marcelo Meloㄹ, Monique Assis ${ }^{3}$, Carlos Gabriel Bustamante ${ }^{4}$, Alexandre Palma ${ }^{1}$}

${ }^{1}$ Escola de Educação Física e Desportos, Universidade Federal do Rio de Janeiro, Rio de Janeiro, Brazil

${ }^{2}$ Escola Politécnica de Saúde Joaquim Venâncio, Fundação Oswaldo Cruz, Rio de Janeiro, Brazil

${ }^{3}$ Universidade Estadual do Rio de Janeiro, Rio de Janeiro, Brazil

${ }^{4}$ Escola Nacional de Saúde Pública Sergio Arouca, Fundação Oswaldo Cruz, Rio de Janeiro, Brazil

Email: cgabrielbustamante@gmail.com

How to cite this paper: Rodrigues, P.A.F., Vilaça, M.M., Melo, M., Assis, M., Bustamante, C.G. and Palma, A. (2016) An Incomplete Discussion on the Costs of Obesity. Open Access Library Journal, 3: e3080. http://dx.doi.org/10.4236/oalib.1103080

Received: September 21, 2016

Accepted: October 21, 2016

Published: October 24, 2016

Copyright $\odot 2016$ by authors and Open Access Library Inc.

This work is licensed under the Creative Commons Attribution International

License (CC BY 4.0).

http://creativecommons.org/licenses/by/4.0/

\begin{abstract}
Despite growing scientific interest in obesity and the uncritical nature of a considerable proportion of the scientific community, a variety of other researchers have queried the idea of an epidemic of obesity. Some of this questioning has highlighted the uncertain moral and ideological nature of the biomedical arguments about the risks of obesity. It should be researchers' responsibility to question whether the hegemonic discourse against obesity has led to a process of stigmatization and apportionment of blame, such that obese individuals are judged as having socially expensive, lazy and dangerous bodies that they do not take care of, and as being bad bio-citizens. It may therefore be of interest, in addition to discussing the onus of obesity, to identify and debate who the "economic problem of obesity" is of concern or interest to, and also who profits (politically and economically) from maintaining this state or combating it. The aim of the present text was not to establish methodological judgment over papers that have addressed the costs associated with obesity. Our objectives were: 1 ) to establish a critique of the non-explicit discourse that stems from these investigations; and 2) to reveal the set of factors that contribute towards such expenditure.
\end{abstract}

\section{Subject Areas}

Health Policy, Public Health, Socioeconomics

\section{Keywords}

Obesity, Lifetime Medical Cost, Cost of Illness

\section{Introduction}

Despite growing scientific interest in obesity and the uncritical nature of a considerable 
proportion of the scientific community, a variety of other researchers have queried the idea of an epidemic of obesity [1]. Some of this questioning has highlighted the uncertain moral and ideological nature of the biomedical arguments about the risks of obesity [1] [2].

If it is supposed, on the one hand, that obesity is an evil that should be combated since it gives rise to serious risks to human health (an idea that we consider to require some caveats), it would be appropriate to analyze how the State has acted in relation to what is known as the "industry of obesity". Even though it is possible to reflect on the potential invasion of private life, if consumption of certain foods contributes towards a state of obesity (under the terms in which it is overwhelmingly perceived), would it not be right to act against their producers, i.e. against those who profit through putting such food on the market? Or should the State take an arms-length stance in relation to this problem, leaving companies free from any co-responsibility and, at the same time, adopt a condemnatory attitude towards the individuals involved?

In other words, it needs to be asked whether the hegemonic discourse against obesity might not be overestimating human autonomy by throwing the burden of "deciding not to be obese" onto individuals, regardless of the context that they experience, the influence that they exert and are subject to, and the limits that are imposed on them. If scientists and public health authorities consider that obesity is a terrible contemporary affliction and understand which types of food contribute towards its occurrence, why do they not include the suppliers of products that lead to obesity in their fight against obesity? From the point of view of those who combat obesity on the grounds of the public and private economic damage that it causes, would it not be coherent to join forces to the maximum extent possible in order to win this "war", even if this implies certain restrictions on access to certain products and on individual freedom to consume them?

Recently, an article under the title "Lifetime Direct Medical Costs of Childhood Obesity" that was published in Pediatrics showed that there was an important difference in healthcare costs between normal-weight and obese children [3].

Public or private expenditure resulting from medical or treatment expenses has frequently been mentioned as a seductive convincement strategy. Through this, the aim is primarily to sustain the idea that we are faced with a severe and complex public health problem with controversial economic implications. Such a situation would theoretically be more serious, insofar as it would have consequences not only for obese individuals but also collectively. For example, there would be consequences relating to maintaining public healthcare systems (in the countries where such systems exist) or with regard to private health insurers, as many studies around the world have sought to demonstrate for decades. Moreover, an attempt to place both moral and legal blame on individuals for behavior that they could change on their own has been seen [4]. In other words, discussion of the onus associated with obesity has led to a process of stigmatization and apportionment of blame, such that obese individuals are judged as having socially expensive and dangerous bodies that they do not take care of, and as being bad bio-citizens [5]. 
We are faced with what Rose and Novas [6] called "biological citizenship". In their view, a new kind of citizenship is taking shape in the age of biomedicine, biotechnology and genomics. We term this "biological citizenship". According to these authors, this represents a new citizenship project. They take this to mean "[...] the ways that authorities thought about (some) individuals as potential citizens, and the ways they tried to act upon them" (p. 1) [6]. In short, a citizenship project involves establishment or imposition (nationally, on all citizens) of instruments, institutions, norms and political, legal, linguistic and educational procedures "[...] in the hope that they would encourage certain ways of thinking, feeling and acting; developing social insurance systems to bind national subjects together in the sharing of risks" (p. 1) [6].

It is precisely the national and therefore theoretically egalitarian dimension of citizenship (national form of citizenship) that is under threat in the biological citizenship project. As stated by Rose and Novas [6], "specific biological presuppositions, explicitly or implicitly, have underlain many citizenship projects, shaped conceptions of what it means to be a citizen, and underpinned distinctions between actual, potential, troublesome and impossible citizens" (p. 2).

In the context of contemporary biopolitics, under the sway of somatic ethics, human life is strongly marked by a process of intense capitalization via molecularization, optimization, subjectivation, expertise and bioeconomics, thus forming a "new molecular ontology of life" [7]. At a historic moment at which vitality may be decomposed, stabilized, manipulated, programmed, frozen, exchanged, negotiated and commercialized, there is an "elective affinity" between somatic ethics and the spirit of biocapital [7].

Thus, it can be considered that this topic involves different issues: not only the sums of money spent on certain programs or treatments but also, primarily, the biopower relationships that become established. It may therefore be of interest, in addition to discussing the onus of obesity, to identify and debate who the "economic problem of obesity" is of concern or interest to, and also who profits (politically and economically) from maintaining this state or combating it [8].

The aim of the present text was not to establish methodological judgment over papers that have addressed the costs associated with obesity. Our objectives were: a) to establish a critique of the non-explicit discourse that stems from these investigations; and $b$ ) to reveal the set of factors that contribute towards such expenditure.

\section{Obesity: Complexity and Detrimental Effects of Economics}

Socioeconomic factors have been considered fundamental in relation to obesity. Some investigations have demonstrated that social inequality is a factor that may contribute enormously towards increased obesity, although this has been observed more strongly in high-income countries [9] [10].

The association between the social condition of a certain group and obesity may be influenced by different factors, but economic factors may have a strong influence on diet. The key to this question may lie in the cost and energy density of given foods [11]. For example, foods based on refined grains, sugars or fats, which have high energy den- 
sity and low nutritional value, are cheaper than foods of low calorie density that are nutritionally rich [12].

One possible explanation for the discrepancy in the prices of foods with different energy densities could be rapid technological development. Over the years, this has made it cheaper to produce manufactured foods and, at the same time, has left them nutritionally poor, thus making the final product cheaper for consumers than foods of low energy density [13]. One example of this is the case of sugary drinks and snacks at fast-food chains, which after correction for inflation have presented price reductions over the years, in contrast to the prices of fruits and vegetables, which have presented an increase [14].

High-income countries that have considerable social inequalities, such as the United States, present high obesity rates, possibly due to production of foods with higher calorie density. Countries with these economic characteristics are more accessible to full technological development relating to food production. Thus, the lower margin of the population of unequal societies is being led towards consumption of products of poor nutritional quality, thus making this group more vulnerable to obesity. Hence, the weight gain would partly be a result from this cycle, in which poverty and obesity would coexist and the financial cost associated with obesity would be just one of the undesired side effects from the search for capital through profit.

One example of this is the food subsidy program in Egypt, which has created a disparity between the prices of highly caloric foods and those of low calories and has led low-income consumers (especially women) to consume highly caloric foods, since these have more accessible prices. Moreover, these subsidized foods present high palatability and accessibility, thus favoring their consumption [15].

The behavior of the State towards agricultural policies for controlling obesity is a complex question and there are great disagreements between experts studying this field. Nonetheless, this discussion is a crucial point for determining obesity [16]-[18]. The point of disagreement regarding subsidies relates to what impact they might have on controlling obesity. According to Alston, even if all the subsidies that the United States provides for agricultural production were to be removed, this would not have any significant influence on controlling obesity. This idea is reinforced by the fact that countries with low obesity rates have also supported their farmers [19].

On the other hand, not removing the subsidies for foods that are the raw materials for nutritionally inferior manufactured foods does not prevent stimuli for production of foods of better quality such as fruits and vegetables. However, this is not what happens. According to Franck (2013), the distribution of subsidies in the United States takes place in an unequal manner. Large-scale farmers who produce monocultures of raw materials for manufactured foods account for $7 \%$ of the farms in the United States but receive a subsidy 29 times greater than that of the smallest farms, which form $76 \%$ of the total number of farms in that country. Also according to that author, this inequality in the distribution of subsidies is a factor that discourages small farmers from cultivating foods such as fruit and vegetables [16]. 
Any economic sector will always be susceptible to certain interest groups. Thus, it would be prudent to reflect on who the removal of subsidies might harm. The interests of the industry go beyond food production in itself. With the advance of monoculture farms, the agrotoxin industry has presented increasingly large profits over the years. Therefore, economic policies that restrict the agricultural market would affect this sector.

It is noteworthy that since the 1970s, the increases in obesity that have occurred in the United States, United Kingdom and South Africa have occurred in consonance with increased use of glyphosate, which is one of the main agrotoxins. This herbicide is widely used on grain crops such as maize, wheat and soybeans and, although the industry states that its toxicity towards humans is minimal, it has been correlated with obesity, heart disease, depression, infertility, autism and Alzheimer's disease, among other health problems [20]. Three hypotheses can be formulated in this regard: firstly, the rise in the obesity prevalence rate over these years might be associated with increased grain production since the 1970s; secondly, use of glyphosate might be directly associated as a factor contributing towards weight gain; and thirdly, there might be a combination of the first and second hypotheses, i.e. increased grain production may have caused greater use of glyphosate and both of these may have contributed towards worsening of obesity as a public health problem.

Within all the complexity involved in the economics of obesity and its worsening, certain decisions may be made to favor public health. Regulation of the market for products associated with weight gain might have positive results for public health programs, similar to what has been seen in relation to the tobacco industry [21]. It is thought that taxation on soft drinks and other sugared drinks would lead to reduction of their consumption, as well as generating estimated revenue of 79 billion dollars over a six-year period, which could be ploughed back into obesity control programs. Regulation of this nature could have an impact, albeit modest, on public health [22]. However, these measures are regarded as inhibition of consumers' right to choose and thus go against the neoliberal perspective that holds sway in most developed and developing countries. Such policies are considered to be excessively paternalistic and need to overcome major challenges, such as lack of political interest and public support [23] [24].

On the other hand, it should not be forgotten that major companies act with different products focusing on income-related consumer strata. In other words, the same company that markets a more expensive soft drink also produces a similar but cheaper one with a view to reaching a lower-income group. Excessive taxation has been rejected by the combined bourgeois classes in many countries, with the implication that tax removal and/or exemption programs are implemented either directly or through subsidies in other taxes, so as not to make the final product more expensive.

The power to change the economics of the current scenario of obesity may be limited, as seen earlier, but there is the potential for changes to be made. Economic policies that aim to control obesity need to move away from the focus on agricultural subsidies alone. Changes need to take place throughout the production process that leads 
to consumers [18].

Because a large proportion of state healthcare authorities are subject to the logic of neoliberal economic policies or to corporate financial interests, and therefore can be seen to be linked to or weakened in relation to the political-economic power game, under circumstances in which certain government bodies still have to cope with the situation, health promotion actions throughout the production chain become more difficult. In this regard, industrial and commercial interests can have important effects on public health policies [25]-[28]. Thus, it can be seen that the food manufacturing and pharmaceutical industries, among others, have sought to establish links with healthcare entities in partnerships known as public-private partnerships (PPPs). The prime aim in these widely questionable and debatable relationships, especially in the field of bioethics, is to increase the financial profits of companies. Moreover, they have other consequences, such as weakening of the messages of public health bodies, protection of companies against hostile legislative effort and improvement of company image in the eyes of consumers. In this manner, the spotlight is removed from companies' large proportion of the blame for increased obesity, which generally involves corruption of the authorities, peddling of influence and conflicts of interest [29]. These partnerships may initially seem to have some advantages for healthcare entities (and this is the message that companies wish to transmit), but healthcare cannot pay the price for sustaining a relationship in which the population may be unscrupulously harmed [17] [30]-[32].

According to Schrempf, companies in the food sector that are socially linked to obesity, particularly fast-food chains and soft drink manufacturers, should take greater social responsibility in relation to their actions, information about their products and control over the harm from their products, since such conduct forms part of business ethics. This would imply adaptations to their marketing and branding, with clarity of content and in relation to the production process for their products [33]. However, in practice, these responsibilities do not materialize and thus children and adolescents in particular become strongly vulnerable to obesity. In fact, perhaps it is not possible to demand conscience from those who may not have any. Companies exist to make profits and do what is needed to achieve these ends, especially with regard to disseminating the message that the company is responsible. Thus, to demand "social responsibility" from companies sounds at best naïve or submissive.

One example of this is seen when fast-food outlets are located close to schools. Students become susceptible towards developing obesity and present changes to their dietary patterns when fast-food establishments exist close to schools [34]. Another example can be seen in relation to advertising for foods that are rich in fats and sugars, which are carried on television at the peak viewing times for child audiences. This advertising makes use of strong emotional resources, offers of free gifts and children's media personalities to publicize these companies' products [35]. In a liberal capitalist world in which profit is regarded by shareholders as the main aim to be attained and freedom of choice is taken to be the reason that justifies certain actions, even though the options are limited, belief in the discourse of social responsibility of the food indus- 
try is, at best, naive.

One example of the perversity of capital relates to the situation of American healthcare companies. The discourse presented by these companies suggests that they are committed to their clients' lives and health, but their incessant search for profit leads to investments that are made in the opposite direction. In this regard, their investments of approximately 4.5 billion dollars in the tobacco industry can be cited [36]. Such actions, which can be considered to be morally questionable, are often observed in advertising for soft drink. These products are carried in the media in association with images of happiness, achievement, friendship and health, when in fact they are no more than highly sugared drinks that are calorie-rich. In many cases, these companies' discourse is supported through promotion of physical activity, which can be seen as an attempt to throw the blame for weight gain onto sedentary lifestyles, thereby dissociating their brands from the problem of obesity [17].

This indicates that the fidelity of capital to the logic of social responsibility always stumbles over the limits imposed by the need for profit. If it is supposed that manufacturers and state authorities know about the effects of these foods and products in relation to obesity, but nonetheless there is no prohibition or even any embargo on putting them on the market, it is plausible to conclude that a deliberate decision to compromise individuals' health has repeatedly been taken.

The authorities responsible for formulating public policies, and also the experts studying this problem, need to understand the process of food choices as plural in nature within the concept of modern society within which we live, in which economic issues, preferences, time constraints and palatability surmount the discourse of healthy eating [37]. To tell a population that is already vulnerable to social shortcomings to consume products that are said to be healthier might be thought of as elitist discourse. Thus, the efforts to control obesity should be introduced in an opposite manner, so as to make this type of food economically more accessible.

Furthermore, in discussing the onus attached to obesity in relation to public or private health, Finkelstein et al. [3] ought to have discussed who generated this cost and who profited from this system. On the contrary, a process of laying the blame on individuals was encouraged, such that obese individuals were regarded as having socially expensive bodies. This discourse needs to be analyzed as problematic, in that personal choices cannot be dissociated from contextual influences. Otherwise, it would be as if individuals were able to choose whether or not to be obese on their own.

\section{References}

[1] Campos, P., Saguy, A., Ernsberger, P., Oliver, E. and Gaesser, G. (2006) The Epidemiology of Overweight and Obesity: Public Health Crisis or Moral Panic? International Journal of Epidemiology, 35, 55-60. http://dx.doi.org/10.1093/ije/dyi254

[2] Gard, M. and Wright, J. (2005) The Obesity Epidemic: Science, Morality and Ideology. Routledge, London.

[3] Finkelstein, E.A., Graham, W.C.K. and Malhotra, R. (2014) Lifetime Direct Medical Costs of Childhood Obesity. Pediatrics, 133, 854-862. http://dx.doi.org/10.1542/peds.2014-0063 
[4] Guttman, N. and Salmon, C.T. (2004) Guilt, Fear, Stigma and Knowledge Gaps: Ethical Issues in Public Health Communication Interventions. Bioethics, 18, 531-552.

http://dx.doi.org/10.1111/j.1467-8519.2004.00415.x

[5] Halse, C., Wright, J. and Harwood, V. (2009) Bio-Citizenship: Virtue Discourses and the Birth of the Bio-Citizen. Biopolitics and the "Obesity Epidemic": Governing Bodies. Routledge, Sydney, AU, 45-59.

[6] Rose, N. and Novas, C. (2003) Biological Citizenship. In: Ong, A. and Collier, S., Eds., Blackwell Companion to Global Anthropology, Blackwell, Oxford.

[7] Rose, N. (2007) Molecular Biopolitics, Somatic Ethics and the Spirit of Biocapital. Social Theory \& Health, 5, 3-29. http://dx.doi.org/10.1057/palgrave.sth.8700084

[8] Rail, G., Holmes, D. and Murray, S.J. (2010) The Politics of Evidence on "Domestic Terrorists": Obesity Discourses and Their Effects. Social Theory \& Health, 8, 259-279.

http://dx.doi.org/10.1057/sth.2009.10

[9] Vogli, R.D., Kouvonen, A. and Gimeno, D. (2014) The Influence of Market Deregulation on Fast Food Consumption and Body Mass Index: A Cross-National Time Series Analysis. Bulletin of the World Health Organization, 92, 99-107A. http://dx.doi.org/10.1057/sth.2009.10

[10] Vogli, R.D., Kouvonen, A., Elovainio, M. and Marmot, M. (2014) Economic Globalization, Inequality and Body Mass Index: A Cross-National Analysis of 127 Countries. Critical Public Health, 24, 7-21. http://dx.doi.org/10.1080/09581596.2013.768331

[11] Costa-Font, J. and Gil, J. (2008) What Lies behind Socio-Economic Inequalities in Obesity in Spain? A Decomposition Approach. Food Policy, 33, 61-73.

http://dx.doi.org/10.1016/j.foodpol.2007.05.005

[12] Drewnowski, A. and Darmon, N. (2005) The Economics of Obesity: Dietary Energy Density and Energy Cost. The American Journal of Clinical Nutrition, 82, 265S-273S.

[13] Finkelstein, E.A., Ruhm, C.J. and Kosa, K.M. (2005) Economic Causes and Consequences of Obesity. Annual Review of Public Health, 26, 239-257. http://dx.doi.org/10.1146/annurev.publhealth.26.021304.144628

[14] Christian, T. and Rashad, I. (2009) Trends in US Food Prices, 1950-2007. Economics \& Human Biology, 7, 113-120. http://dx.doi.org/10.1016/j.ehb.2008.10.002

[15] Asfaw, A. (2007) Do Government Food Price Policies Affect the Prevalence of Obesity? Empirical Evidence from Egypt. World Development, 35, 687-701. http://dx.doi.org/10.1016/j.worlddev.2006.05.005

[16] Franck, C., Grandi, S.M. and Eisenberg, M.J. (2013) Agricultural Subsidies and the American Obesity Epidemic. American Journal of Preventive Medicine, 45, 327-333. http://dx.doi.org/10.1016/j.amepre.2013.04.010

[17] Freedhoff, Y. (2014) The Food Industry Is Neither Friend, Nor Foe, Nor Partner. Obesity Reviews, 15, 6-8. http://dx.doi.org/10.1111/obr.12128

[18] Hawkes, C., Friel, S., Lobstein, T. and Lang, T. (2012) Linking Agricultural Policies with Obesity and Noncommunicable Diseases: A New Perspective for a Globalising World. Food Policy, 37, 343-353. http://dx.doi.org/10.1016/j.foodpol.2012.02.011

[19] Alston, J.M., Sumner, D.A. and Vosti, A.S. (2008) Farm Subsidies and Obesity in the United States: National Evidence and International Comparisons. Food Policy, 33, 470-479. http://dx.doi.org/10.1016/j.foodpol.2008.05.008

[20] Samsel, A. and Seneff, S. (2013) Glyphosate's Suppression of Cytochrome P450 Enzymes and Amino Acid Biosynthesis by the Gut Microbiome: Pathways to Modern Diseases. Entropy, 15, 1416-1463. http://dx.doi.org/10.3390/e15041416 
[21] Pomeranz, J.L. (2014) Sugary Beverage Tax Policy: Lessons Learned from Tobacco. American Journal of Public Health, 104, e13-e15. http://dx.doi.org/10.2105/ajph.2013.301800

[22] Andreyeva, T., Chaloupka, F.J. and Brownell, K.D. (2011) Estimating the Potential of Taxes on Sugar-Sweetened Beverages to Reduce Consumption and Generate Revenue. Preventive Medicine, 52, 413-416. http://dx.doi.org/10.1016/j.ypmed.2011.03.013

[23] Jou, J. and Techakehakij, W. (2012) International Application of Sugar-Sweetened Beverage (SSB) Taxation in Obesity Reduction: Factors That May Influence Policy Effectiveness in Country-Specific Contexts. Health Policy, 107, 83-90. http://dx.doi.org/10.1016/j.healthpol.2012.05.011

[24] Kass, N., Hecht, K., Paul, A. and Birnbach, K. (2014) Ethics and Obesity Prevention: Ethical Considerations in 3 Approaches to Reducing Consumption of Sugar-Sweetened Beverages. American Journal of Public Health, 104, 787-795. http://dx.doi.org/10.2105/AJPH.2013.301708

[25] Jasso-Aguilar, R., Waitzkin, H. and Landwehr, A. (2004) Multinational Corporations and Health Care in the United States and Latin America: Strategies, Actions, and Effects. Journal of Health and Social Behavior, 45, 136-157.

[26] Szreter, S. and Woolcock, M. (2004) Health by Association? Social Capital, Social Theory, and the Political Economy of Public Health. International Journal of Epidemiology, 33, 650-667. http://dx.doi.org/10.1093/ije/dyh013

[27] Waitzkin, H., Jasso-Aguilar, R., Landwehr, A. and Mountain, C. (2005) Global Trade, Public Health, and Health Services: Stakeholders' Constructions of the Key Issues. Social Science \& Medicine, 61, 893-906. http://dx.doi.org/10.1016/j.socscimed.2005.01.010

[28] Jasso-Aguilar, R., Waitzkin, H. and Landwehr, A. (2011) Multinational Corporations, the State, and Contemporary Medicine. Health Sociology Review, 20, 245-257. http://dx.doi.org/10.5172/hesr.2011.20.3.245

[29] Robim, M.M. (2010) The World According to Monsanto: Pollution, Corruption, and the Control of the World's Food Supply. The New Press, New York.

[30] Heim, L. (2010) Identifying and Addressing Potential Conflict of Interest: A Professional Medical Organization's Code of Ethics. The Annals of Family Medicine, 8, 359-361. http://dx.doi.org/10.1370/afm.1146

[31] Moynihan, R. (2006) Obesity Task Force Linked to WHO Takes “Millions" from Drug Firms. BMJ, 332, 1412. http://dx.doi.org/10.1136/bmj.332.7555.1412-a

[32] Susman, J. (2009) Do Things Really Go Better with Coke? The Journal of Family Practice, 58, 630 .

http://www.jfponline.com/the-publication/past-issue-single-view/do-things-really-go-bette r-with-coke/74d40a2b7371c24b9c38d584fa36355f.html

[33] Schrempf, J. (2014) A Social Connection Approach to Corporate Responsibility: The Case of the Fast-Food Industry and Obesity. Business \& Society, 53, 300-332. http://dx.doi.org/10.1177/0007650312449577

[34] Davis, B. and Carpenter, C. (2009) Proximity of Fast-Food Restaurants to Schools and Adolescent Obesity. American Journal of Public Health, 99, 505-510. http://dx.doi.org/10.2105/AJPH.2008.137638

[35] Batada, A., Seitz, M.D., Wootan, M.G. and Story, M. (2008) Nine out of 10 Food Advertisements Shown during Saturday Morning Children's Television Programming Are for Foods High in Fat, Sodium, or Added Sugars, or Low in Nutrients. Journal of the American Dietetic Association, 108, 673-678. http://dx.doi.org/10.1016/j.jada.2008.01.015

[36] Boyd, J.W., Himmelstein, D. and Woolhandler, S. (2009) Insurance-Industry Investments 
in Tobacco. New England Journal of Medicine, 360, 2483-2484.

http://dx.doi.org/10.1056/NEJMc0901817

[37] Blaylock, J., Smallwod, D., Kassel, J., Variyam, J. and Aldrich, L. (1999) Economics, Food Choices, and Nutrition. Food Policy, 24, 269-286.

http://dx.doi.org/10.1016/S0306-9192(99)00029-9

Submit or recommend next manuscript to OALib Journal and we will provide best service for you:

- Publication frequency: Monthly

- 9 subject areas of science, technology and medicine

- Fair and rigorous peer-review system

- Fast publication process

- Article promotion in various social networking sites (LinkedIn, Facebook, Twitter, etc.)

- Maximum dissemination of your research work

Submit Your Paper Online: $\underline{\text { Click Here to Submit }}$

Or Contact service@oalib.com 